\title{
Effects of Nanoencapsulated Carotenoid of Spirulina platensis on the Sensory Profiles of Dark and Milk Chocolate
}

\author{
Asep Bayu Hamdan, Ciacia Riaty, Wahdan Fitriya, and Nurfitri Ekantari* \\ Fish Processing Technology, Fisheries Department, Faculty of Agriculture, Universitas Gadjah Mada
}

\begin{abstract}
The addition of Spirulina platensis in chocolate bar was reported to be able to increase the carotenoid content. Unfortunately, the fortified dry biomass generated fishy odor. In recent years, we succeeded to extract carotenoid from $S$. platensis, which was then encapsulated using a mixture of gum arabic and WPC by nanoemulsion technique. It helped reduce the fishy odor and concentrate carotenoid content in the nanocapsules. This study aimed to determine the effect of $S$. platensis's carotenoid nanocapsules on the flavor profiles of dark and milk chocolate. The S. platensis's carotenoid nanocapsules were added at a dose of $0.37 \%(\mathrm{w} / \mathrm{w})$. Flavor profiles were detected using Gas Chromatography-Mass Spectrometry. A total of 79 aroma active were detected. The dark chocolate had a specific aroma of strong acidic chocolate, enriched with creamy and sweet. Meanwhile, the milk chocolate was dominated by creamy, cheesy, and sweet. The fortified chocolate had lower concentration of acids and aldehydes but had higher pyrazines and alcohols. Volatile compound that responsible for the fishy odor in Spirulina platensis was not detected in fortified chocolate. In conclusion, the fortification increased the intensity of sweet and chocolate flavor, decreased the bitter and sour flavor, and did not generate any unpleasant odor.
\end{abstract}

\section{Introduction}

Spirulina platensis is a widely spread microalgae that can be found in various types of environments, either in brackish, marine, or freshwater [1]. This autotrophic unbranched blue-green microalga is characterized by the filaments composed of spiral-shaped multicellular trichomes and a columned cell forming a spiral-shaped twisted filament. Spirulina platensis has a protein content of $60 \%-69 \%$, a fat content of 5\% - 7\%, carbohydrate content of $16 \%-20 \%$, and carotenoid levels of $650 \mathrm{mg} / 100 \mathrm{gram}$. Spirulina platensis is a microalga that is rich in provitamin A carotenoids such as $\beta$-carotene. Spirulina platensis has at least 50 times higher $\beta$-carotene levels than carrots, making it an excellent material to increase $\beta$-carotene levels in various types of food products [2].

Spirulina platensis contains important bioactive compounds that are useful for the growth and health of the human body, such as sulfolipids, omega 3, omega 6, and omega 8 . Sulfolipid compounds in spirulina have an important role in the human body in maintaining

*Corresponding author: nurfitri@ugm.ac.id 
the body's resistance. Sulfoquinovosyl diacylglycerol (SQDG) compound is one of the sulfolipids extracted from Spirulina platensis, and it can be an inhibitor of herpes simplex virus type 1 (HSV-1) which can damage the human immune system [3]. High nutrition and bioactive compounds in Spirulina platensis can be a solution to the problem of malnutrition in various countries, such as vitamin A deficiency and hunger edema. The addition of 10 grams of Spirulina platensis into local food products in Kisantu area of the Democratic Republic of Congo could reduce the number of children with malnutrition from $30 \%$ to $20 \%$ in the area [4].

The use of Spirulina platensis in healthy food industries has been widely carried out. Besides being easily digested, these microalgae contain compounds needed by the human body, such as protein, lipids, carbohydrates, unsaturated fatty acids, vitamins, minerals, amino acids, and several types of pigments that are quite useful. This microalga has been used as a medicine, and the dried powder is used as well-being food which is marketed in certain countries such as Spain, Switzerland, Australia, Japan, and America [2]. The disadvantages of Spirulina platensis are the fishy odor disliked by consumers and the grainy texture due to the large particles of the microalgae [5]. These problems become obstacles in the study of the addition of dry biomass Spirulina platensis into chocolate bars carried out by Negara [6].

The study added $0 \%, 5 \%, 10 \%$, and $15 \%$ Spirulina platensis dry biomass to the chocolate bar, and it was found that chocolate added with 5\% dry biomass was the most preferred chocolate. The addition of 5\% Spirulina platensis dry biomass to the chocolate bar could increase $\beta$-carotene levels from $114 \mu \mathrm{g} / 30 \mathrm{~g}$ to $2344 \mu \mathrm{g} / 30 \mathrm{~g}$. However, the addition of Spirulina platensis dry biomass gave the panelist an unwelcome odor. This fishy odor is caused by the presence of Eicosapentaenoic Acid and Docosahexaenoic Acid compounds, which are Omega-3 compounds from Spirulina platensis [7]. The addition of Spirulina platensis dry biomass could also cause grainy texture in the chocolate bar due to the large particles of Spirulina platensis biomass. This is contrary to the principle of fortification, stating that a fortification process must be able to maintain the original nature of the food vehicle used [8]. The fishy odor of Spirulina platensis can be removed by the extraction and nanoencapsulation of carotenoids in Spirulina platensis [9].

Nanoencapsulation technology is a technique that makes a wall layer physically isolating material from the outside environment. The application of nanoencapsulation in materials can prevent oxidation, heat damage, and photooxidation. This ability allows materials that have high sensitivity, such as carotenoids in spirulina, to be maintained both in quality and quantity during the fortification process [10]. Department of Fisheries, Universitas Gadjah Mada has successfully extracted carotenoids from Spirulina platensis and conducted nanoencapsulation using a mixture of whey protein concentrate (WPC) and gum arabic with nanoemulsion techniques. The extraction and nanoencapsulation of carotenoids from Spirulina platensis could increase the total carotenoid concentration from $4 \mathrm{mg} / \mathrm{g}$ to $45 \mathrm{mg} / \mathrm{g}$ and $\beta$-carotene content from $1.5 \mathrm{mg} / \mathrm{g}$ to $22.3 \mathrm{mg} / \mathrm{g}$ [11].

Chocolate production in Indonesia reached 688,345 tons in 2017 and is expected to be increasing [12]. Children in Indonesia mostly prefer milk chocolate compared to dark chocolate. Dark chocolate itself is chosen as a health food product because it has lower levels of calories and sugar and has antioxidant value two times higher compared to milk chocolate, which is equal to 13,120 ORAC (oxygen radical absorbance capacity) [13]. The addition of carotenoid nanocapsules of Spirulina platensis into the dark and milk chocolate is expected to create a product that is rich in $\beta$-carotene but does not change the flavor characteristics of the chocolate product itself.

GC-MS (gas chromatography-mass spectrophotometry) is an extraction method to detect volatile compounds responsible for the appearance of flavor characteristics in a product [14]. In this study, this method was used to detect volatile compounds in the chocolate to determine 
the effect of the addition of the Spirulina platensis carotenoid nanocapsules on the flavor characteristics of dark and milk chocolate.

\section{Materials and methods}

\subsection{Materials}

Ingredients used for chocolate were fermented cocoa beans from cocoa farmers in Kalibawang Kulon Progo Regency, refined sugar, cocoa butter, soy lecithin, milk powder, baking soda, and Spirulina platensis carotenoid nanocapsules from the Fish Processing Technology Laboratory, Department of Fisheries, Universitas Gadjah Mada. Meanwhile, materials used for GC-MS testing were SPME fiber and DB-Wax column (30 m x $250 \mu \mathrm{m} \mathrm{x}$ $0.25 \mu \mathrm{m})$.

\subsection{Methods}

\subsubsection{Chocolate production}

The production of dark and milk chocolate in this study referred to the original recipe of the local chocolate industry, KWT Pawon Gendis located in Kulon Progo Regency, with the addition of $0.372 \%$ Spirulina platensis carotenoid nanocapsules. The recipe can be seen in Table 1.

\subsubsection{The determination of aroma profile (GC-MS)}

GC-MS testing was carried out on four samples namely dark chocolate without fortification of nanocapsules carotenoid of Spirulina platensis (DC), dark chocolate with fortification (DS), milk chocolate without fortification (MC), and milk chocolate with fortification (MS). Five grams of chocolate sample was extracted in an SPME vial at a temperature of $55^{\circ} \mathrm{C}$ for 30 minutes. The GC-MS device was conditioned with the carrier gas Hydrogen of 2.5 $\mathrm{mL} / \mathrm{minute}$, the interface of 250C, MS Source of 150C, MS Quad 150C, and scan mass of 29-550 amu. Oven program was set at $40^{\circ} \mathrm{C}$, in which the temperature was increased $5^{\circ} \mathrm{C} /$ minute to $220^{\circ} \mathrm{C}$ and then increased $4^{\circ} \mathrm{C} /$ minute to $230^{\circ} \mathrm{C}$ for 2 minutes. The principle of separation with GC-MS is the spread of sample mixture through the stationary phase with the gas, as a mobile phase, eluting the stationary phase. The mechanism of GC is a mobile phase in the form of gas flowing under pressure through a pipe that is heated and coated with a liquid stationary phase or packed with a liquid stationary phase which is coated on a solid buffer. The analyte is loaded into the top of the column through a heated injection portal. Oven temperature is maintained or programmed to increase gradually. the separation of components occurs in the column. This separation will depend on the relative length of time required by these components in the stationary phase [14]. 
Table 1. Chocolate ingredients and the addition of nanocapsules

\begin{tabular}{|l|c|c|c|c|}
\hline \multirow{2}{*}{ Ingredients } & \multicolumn{2}{|c|}{ Dark Chocolate } & \multicolumn{2}{c|}{ Milk Chocolate } \\
\cline { 2 - 5 } & DC & DS & MC & MS \\
\hline Cocoa Butter & $30.00 \%$ & $30.00 \%$ & $27.50 \%$ & $27.50 \%$ \\
\hline Cocoa Paste & $40.00 \%$ & $40.00 \%$ & $25.00 \%$ & $25.00 \%$ \\
\hline Granulated Sugar & $18.50 \%$ & $18.50 \%$ & $22.50 \%$ & $22.50 \%$ \\
\hline Milk Powder & $11.50 \%$ & $11.50 \%$ & $25.00 \%$ & $25.00 \%$ \\
\hline Backing Soda & $0.30 \%$ & $0.30 \%$ & $0.30 \%$ & $0.30 \%$ \\
\hline Vanilla & $0.10 \%$ & $0.10 \%$ & $0.10 \%$ & $0.10 \%$ \\
\hline Soy Lecithin & $0.30 \%$ & $0.30 \%$ & $0.30 \%$ & $0.30 \%$ \\
\hline $\begin{array}{l}\text { Nanoencapsulated Carotenoid } \\
\text { of Spirulina platensis }\end{array}$ & - & $0.372 \%$ & - & $0.372 \%$ \\
\hline
\end{tabular}

\section{Results and Discussion}

The chocolate flavor was tested using QDA (quantitative descriptive analysis) by the method of Meilgard [15] in a previous study showing the characteristics of bitter, typical chocolate, sweet, milky and creamy, and acidic. The detected flavor and volatile compounds responsible for the appearance of the flavor can be seen in Table 2 .

Table 2. Chocolate flavor and related volatile compound

\begin{tabular}{|l|c|}
\hline \multicolumn{1}{|c|}{ Flavor } & Related Volatile Compound \\
\hline Bitter & Aldehyde \\
\hline Chcocolate & Pyrazine \\
\hline Sweet & Alcohols (Penyethyl Alcohol) \\
\hline Creamy and Milky & Alcohols (2,3-Butanediol) \\
\hline Sour & Acid (Acetic Acid) \\
\hline
\end{tabular}

Based on Table 2, the main components of the volatile compounds in chocolate can be classified into four main groups of compounds, namely alcohol, aldehyde, pyrazine, and acidic compounds. Alcohol is responsible for sweet and creamy flavors in chocolate, aldehydes are responsible for bitter flavors, acetic acid is responsible for acid flavors, and pyrazine is responsible for chocolate's distinctive flavor [16].

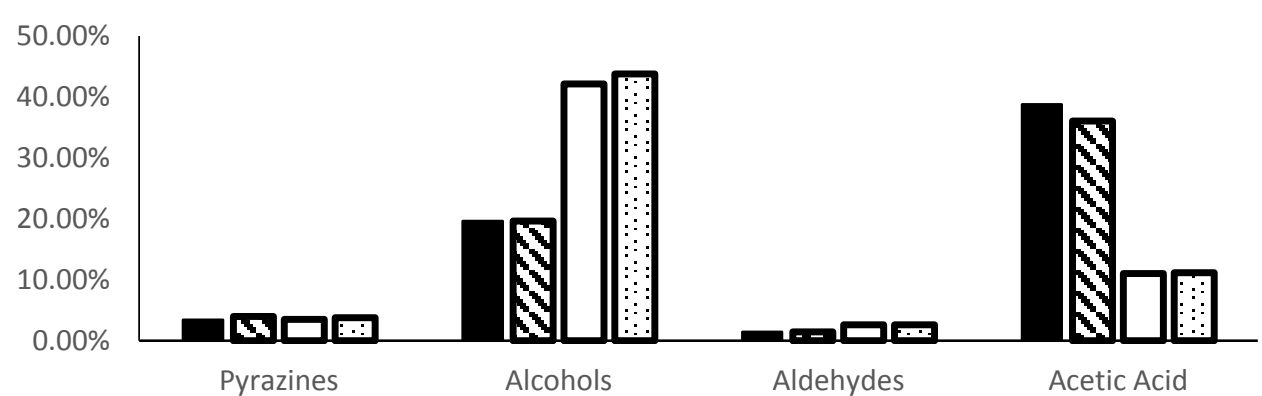

Dark Chocolate DDark Chocolate Spirulina DMilk Chocolate $\mathbf{D}$ Milk Chocolate Spirulina

Figure 1. Concentration of volatile compounds in chocolate 
Table 3. Alcohol components

\begin{tabular}{|l|c|c|c|c|c|}
\hline \multirow{2}{*}{ Compound } & \multicolumn{4}{|c|}{$\%$ Unit Area } & \multirow{2}{*}{ Odour (TGSC, 2018) } \\
\cline { 2 - 5 } & DC & DS & MC & MS & \\
\hline 2-Pentanol, acetate & $0.22 \%$ & $0.36 \%$ & $0.25 \%$ & $0.20 \%$ & Herbal, Weedy, Green \\
\hline $\begin{array}{l}\text { 3-Penten-1-ol, 2- } \\
\text { methyl- }\end{array}$ & - & $0.28 \%$ & $0.30 \%$ & $0.41 \%$ & - \\
\hline $\begin{array}{l}\text { 1-Butanol, 3-methyl-, } \\
\text { acetate }\end{array}$ & $1.57 \%$ & $1.83 \%$ & $6.17 \%$ & $4.90 \%$ & Fruity \\
\hline 2-Heptanol, acetate & $0.83 \%$ & $1.07 \%$ & - & $0.67 \%$ & Brown \\
\hline 2-Heptanol & $2.21 \%$ & $2.83 \%$ & $2.71 \%$ & $2.47 \%$ & - \\
\hline Actylol & $0.79 \%$ & $0.75 \%$ & - & - & Sweet, Fruity, Creamy \\
(Buttery)
\end{tabular}

Figure 1 shows an increase and decrease in the content of volatile compounds in the samples. Fortified dark chocolate contained a lower amount of acetic acid compounds $(36.07 \%)$ than dark chocolate without fortification $(38.79 \%)$. However, fortified milk chocolate and milk chocolate without fortification had almost the same levels of acetic acid compounds, which were $11.095 \%$ and $11.178 \%$, respectively. The lower content of acetic acid in milk chocolate compared to that in dark chocolate is because dark chocolate has more cocoa paste content than milk chocolate, and chocolate originating from the island of Java has a sour taste character [16].

Alcohols are responsible for the sweet and creamy flavor in the chocolate product. This compound is formed during the fermentation process of cocoa beans. The alcohol compound in chocolate is the desired flavor compound in chocolate products to produce naturally sweet flavors and aromas. The alcohol compound giving sweet flavor in chocolate is the phenyl ethyl alcohol compound. Table 3 shows that Butanediol and Penhyl Ethyl Alcohol are the alcohol compounds with the highest concentration among other alcohol compounds in the product. These compounds give the sweet, creamy, buttery, and sweet as honey flavor [17]. The alcohol compounds giving sweet and creamy flavor to chocolate, Butanediol and Penhyl Ethyl Alcohol, had a greater concentration in fortified chocolate compared to in chocolate without fortification both in milk chocolate and dark chocolate. These results indicate that the addition of nanocapsules can increase the sweet flavor of the product. This is possible 
because gum arabic in the carotenoid Spirulina platensis nanocapsules has sweet flavor characteristics.

Table 4. Aldehydes components

\begin{tabular}{|c|c|c|c|c|c|}
\hline \multirow{2}{*}{ Compound } & \multicolumn{4}{|c|}{$\%$ Unit Area } & \multirow{2}{*}{ Odor (TGSC, 2018) } \\
\cline { 2 - 5 } & DC & DS & MC & MS & \\
\hline Benzaldehyde & $0.97 \%$ & $1.15 \%$ & $2.34 \%$ & $2.33 \%$ & Bitter Fruity \\
\hline Benzeneacetaldehyde & $0.48 \%$ & $0.29 \%$ & $0.27 \%$ & $0.26 \%$ & Green \\
\hline Total & $1.46 \%$ & $1.44 \%$ & $2.61 \%$ & $2.59 \%$ & \\
\hline
\end{tabular}

Aldehydes are volatile compounds responsible for the bitter taste in chocolate. Aldehydes in food products are formed from the degradation of Strecker in the Maillard reaction during the roasting process [18]. Aldehydes in the chocolate are formed in 2 stage during the process of making chocolate. The first stage occurs during the fermentation of cocoa beans on day 6 to 8 , and the second stage occurs in the roasting process at a temperature above $70^{\circ} \mathrm{C}$ [17]. Aldehydes detected in this study are Benzaldehyde and Benzeneacetaldehyde (Table 4). Benzaldehydes are compounds that give the impression of bitterness (bitter), and Benzeneacetaldehyde gives the impression of a green taste (floral taste in fruits or green vegetables). Chocolate without fortification had a higher content of aldehydes compared to fortified chocolate, both dark and milk chocolate. The levels of aldehydes decreased by $0.02 \%$ in both types of chocolate. Based on the content of aldehyde in the chocolate, the addition of nanocapsules did not have such a big effect because the decrease in the levels of aldehyde compounds was only $0.02 \%$.

Table 5. Pyrazines components

\begin{tabular}{|l|c|c|c|c|l|}
\hline \multirow{2}{*}{ Compound } & \multicolumn{4}{|c|}{$\%$ Unit Area } & \multirow{2}{*}{ Odour (TGSC, 2018) } \\
\cline { 2 - 5 } & DC & DS & MC & MS & \\
\hline Pyrazine, 2,5-dimethyl- & $0.43 \%$ & $0.43 \%$ & $0.41 \%$ & $0.40 \%$ & Cocoa, Roasted Cocoa \\
\hline Pyrazine, 2,6-dimethyl- & $0.37 \%$ & $0.39 \%$ & $0.38 \%$ & $0.54 \%$ & Nutty, Cocoa \\
\hline $\begin{array}{l}\text { Pyrazine, 2,3-dimethyl- } \\
\text { Pyrazine, 2-ethyl-5- } \\
\text { methyl- }\end{array}$ & $0.13 \%$ & $0.13 \%$ & $0.21 \%$ & $0.21 \%$ & Roasted cocoa skin, Nutty \\
\hline Pyrazine, trimethyl- & $1.04 \%$ & $0.70 \%$ & $1.17 \%$ & $1.21 \%$ & Coffee, Nutty \\
\hline Pyrazine, tetramethyl- & $0.92 \%$ & $1.09 \%$ & $1.08 \%$ & $1.11 \%$ & $\begin{array}{l}\text { Nutty, Cocoa, Brown, } \\
\text { Chocolate Coffee }\end{array}$ \\
\hline Pyrazine, Methil & - & - & - & - & $\begin{array}{l}\text { Nutty, Cocoa, Roasted } \\
\text { Peanut }\end{array}$ \\
\hline Total & $3.45 \%$ & $3.96 \%$ & $3.51 \%$ & $3.75 \%$ & \\
\hline
\end{tabular}

Table 5 shows the component levels of the pyrazine compounds in each chocolate. The levels of pyrazine compounds detected in dark chocolate were $3.45 \%$ for chocolate without fortification and $3.96 \%$ for fortified chocolate. Meanwhile, the levels of pyrazine in milk chocolate were $3.5 \%$ for chocolate without fortification and $3.75 \%$ for fortified chocolate. Although only detected around $3 \%$, pyrazines were able to become the dominant flavor in chocolate because pyrazines have a very small threshold compared to other compounds. The average pyrazines had a lower threshold of $400 \mathrm{ppb}$ compared to other compounds, such as acetic acid which had the highest levels and high threshold of $15 \mathrm{ppm}$ [19]. The levels of 
pyrazines in both types of chocolate, increased by $0.51 \%$ (dark chocolate) and $0.24 \%$ (milk chocolate). The level of pyrazines in dark chocolate was relatively higher compared to that in milk chocolate due to the higher cocoa level in dark chocolate.

Table 6. Volatile compounds of Spirulina platensis [20]

\begin{tabular}{|c|c|c|c|c|}
\hline Compound & DC & DS & MC & MS \\
\hline Pyrazine, 2,5-dimethyl- & $\begin{array}{c}2452919 \\
(0.43 \%)\end{array}$ & $\begin{array}{c}2203554 \\
(0.43 \%)\end{array}$ & $\begin{array}{c}1910754 \\
(0.41 \%)\end{array}$ & $\begin{array}{c}1862107 \\
(0.40 \%)\end{array}$ \\
\hline Pyrazine, trimethyl- & $\begin{array}{c}5878506 \\
(1.04 \%)\end{array}$ & $\begin{array}{c}6283958 \\
(1.23 \%)\end{array}$ & $\begin{array}{c}1217852 \\
(0.26 \%)\end{array}$ & $\begin{array}{c}1318081 \\
(0.28 \%)\end{array}$ \\
\hline 2-Hexanone, 5-methyl- & $\begin{array}{c}9014664 \\
(1.6 \%)\end{array}$ & $\begin{array}{c}7877164 \\
(1.54 \%)\end{array}$ & $\begin{array}{c}1151003 \\
(0.25 \%)\end{array}$ & $\begin{array}{c}9988613 \\
(2.14 \%)\end{array}$ \\
\hline 2-Hexanol, 5-methyl- & $\begin{array}{c}3047753 \\
(0.54 \%)\end{array}$ & $\begin{array}{c}3110123 \\
(0.61 \%)\end{array}$ & $\begin{array}{c}740248 \\
(0.16 \%)\end{array}$ & $\begin{array}{c}863093 \\
(0.18 \%)\end{array}$ \\
\hline 1,6-Heptadien-3-yne & - & - & - & $\begin{array}{c}509958 \\
(0.11 \%)\end{array}$ \\
\hline $\begin{array}{c}\text { Cyclopentane, 1-ethyl-2- } \\
\text { methyl-, cis- }\end{array}$ & - & - & - & $\begin{array}{c}884252 \\
(0.19 \%)\end{array}$ \\
\hline Eicosapentanoic Acid & - & - & - & - \\
\hline Docosahexanoic Acid & - & - & - & - \\
\hline
\end{tabular}

Table 6 shows the volatile compounds of Spirulina platensis from the study of Aguero et al. [20] detected in all four chocolates as well as volatile compounds responsible for the fishy odor in Spirulina platensis. Table 6 shows that there were six compounds detected, in which four of the six compounds were detected in all types of chocolate. It means the chocolate already has the characteristics given from the four types of volatile compounds. Meanwhile, the other two compounds were only detected in the fortified milk chocolate. However, those two compounds do not have the character of taste and aroma or are known as flavorless or odorless. These results indicate that the addition of nanocapsules to chocolate products does not have a great flavor effect because the flavors that emerge from the nanocapsules are already owned by the chocolate products, while the new compounds arising from the addition of nanocapsules themselves do not give any flavor effect because they are flavorless or odorless. Volatile compounds that are responsible for the fishy odor in Spirulina platensis have not been detected in the four chocolates. These results are also proven by the study of Machado et al. [9], stating that encapsulation of a substance contained in Spirulina platensis could eliminate undesirable flavors such as fishy flavor. The encapsulation process only binds the desired substance, such as protein and $\beta$-carotene, resulting in flavor loss of the material used.

\section{Conclusion}

The addition of nanoencapsulated carotenoid from Spirulina platensis increased the intensity of sweet and chocolate flavor, decreased the bitter and sour flavor, and did not generate any unpleasant odor such as fishy odor. 


\section{References}

1. O. Ciferri. Microbiol. Rev. 47, 551-578 (1983)

2. M. Christwardana, M.M.A. Nur, and Hadiyanto. Jurnal Aplikasi Teknologi Pangan 2, 14 (2013)

3. N. Chirasuan, R. Chaiklahan, P. Kittakoop, W. Chanasattru, M. Ruengjitchatchawalya, M. Tanticharoen, \& B. Bunnag. Science Asia 35, 137-141 (2009).

4. F. K. Matondo, K. Takaisi, A. B. Nkuadiolandu, L. A. Kazadi, \& M. N. Aloni. International Journal of Paediatrics (2016).

5. D. A. Setyaningsih, A. Apriyantono., and M. P. Sari. Analisis Sensori untuk Industri Pangan dan Agro (IPB Press, Bogor, 2010).

6. H.P. Negara, I.Y. B. Lelana, and N. Ekantari. Jurnal Perikanan 16: 17-28 (2014).

7. L. M. Andrade, C.J. Andrade., M. Dias., C. AO. Nascimento., and M. A. Mendes. MOJ Food Processing Technology 6, 2 (2018).

8. Prihananto. Fortifikasi Pangan Sebagai Upaya Penanggulangan Anemia Gizi Besi (IPB, Bogor, 2004).

9. A. R. Machado, L. M. Assis., M. R. G. Machado., and L. A. Soza Soarez. International Food Research Journal 22 (1): 344-350 (2015).

10. L. M. Assis, E. R. Zavareze., C. Prentice-Hernandéz., and L. A. Soza-Soares. Brazilian Journal Food Technology 15, 2, 99-109 (2012).

11. E. W. Juliantoro. Fakultas Pertanian. Universitas Gadjah Mada. Skripsi (2019).

12. Ministry of Agriculture. Statistik Perkebunan Indonesia 2017 (Directorate General of Estate Corps. Indonesia (2017).

13. R. M. D. Kelishadi. ARYA Journal 1, 1, 28-34 (2005).

14. O. Sparkman, D., Z. Penton., and G. Fulton. Gas Chromatography and Mass Spectrometry: A Practical Guide. (Elsevier, California, 1996)

15. M. Meilgaard, G. V. Civille, and B. T. Carr. 2007. Sensory Evaluation Techniques. Forth Edition (CRC Press, New York, 2007).

16. I. Kusumaningrum, C. H. Wijaya., F. Kusnandar., Misnawi., and A B. T. Sari. J. Taknologi dan Industri Pangan 25, 1 (2014).

17. L. Ramos, D. R. Dias., M. G. M. da Cruz., S. R. Freitas. Food Research International 64, 908-918 (2014).

18. M.A.J.S van Boekel. Biotechnology Advances 24, 230-233 (2006).

19. TGSC. Fragrance and Volatile Compound Database. The Good Scents Company (2018).

20. J. Aguero, J. Lora., K. Estrada., F. Concepcion., A. Nunez., A. Rodriguez., and J. A. Pino. Jurnal of Essential Oil Research 15, 2, 114-117 (2003). 